\author{
BRAZILIAN JOURNAL \\ $\mathrm{OF}$ \\ RADIATION SCIENCES \\ 05-03-A (2017) 01-08
}

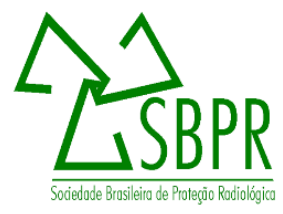

\title{
Sensitivity of the IRD whole-body counter for in vivo measurements in the case of accidental intakes
}

\author{
B.M. Dantas; E.A. Lucena and A.L.A. Dantas \\ Instituto de Radioproteção e Dosimetria-CNEN, Divisão de Dosimetria \\ Av. Salvador Allende - 22780-160, Rio de Janeiro - RJ, Brasil \\ bmdantas@ird.gov.br
}

\begin{abstract}
Intakes of radionuclides by humans may occur in the fuel cycle, nuclear medicine, biological research and in TENORM industries and in case of accidents involving workers and the general public. In vivo monitoring is recognized as a useful tool for the evaluation of such exposures. The IRD whole-body counter consists of a shielded room equipped with four HPGe and two $\mathrm{NaI}(\mathrm{Tl})$ detectors. The system is able to identify and quantify photon emitters in the range from 10 to $3000 \mathrm{keV}$. The minimum detectable activities for most of the radionuclides of interest allow occupational monitoring as well as evaluation of accidental intakes.
\end{abstract}

Keywords: internal dosimetry, in vivo measurement, whole-body counter 


\section{INTRODUCTION}

Exposure to radioactive materials may occur as a result of a variety of professional human activities, such as in (i) nuclear industry; (ii) use of unsealed sources in nuclear medicine, biological research and agriculture; (iii) production of radiopharmaceuticals, as well as in (vi) mining and milling of minerals in which radioactive materials are naturally present.

The Brazilian Nuclear Energy Commission is responsible for the evaluation and approval of Radiation Protection Programmes. In this scope, internal dosimetry laboratories should play an important role by performing reliable measurements and providing technical assistance to the facilities for the design of the monitoring programmes [1].

In vivo measurement techniques aimed to identify and quantify radionuclides in the human body are recommended as a tool for the evaluation of internal exposures. The measurements are performed as part of routine monitoring programmes and are also useful for the estimation of the severity of accidents involving intakes of radioactive materials. [2].

In general terms, the methodology consists in determining the activity in specific organs, tissues or in the whole body. Afterwards, by assuming an exposure scenario and applying the appropriate dosimetric and biokinetic model of the radionuclide of interest, it is possible to estimate the committed effective dose associated to the intake [3].

This work presents the methodologies applied at the In vivo Monitoring Laboratory of IRD for the direct measurement of radionuclides in organs and tissues of the human body.

\section{MATERIALS AND METHODS}

\subsection{Shielded room}

The shielding used in radiometric measurements is aimed to reduce background level associated to the presence of naturally occurring radionuclides from uranium and thorium series as well as $40 \mathrm{~K}$, and also to the interaction of cosmic rays with the atmosphere and building materials.

The IRD whole-body counter shielded room has internal dimensions of $2.5 \mathrm{~m}$ x $2.5 \mathrm{~m} \times 2.62 \mathrm{~m}$. The walls are made of steel and have a graded-Z interior lining made of $3 \mathrm{~mm}$ of lead, $1.5 \mathrm{~mm}$ of 
cadmium and $0.5 \mathrm{~mm}$ of copper. Such thin layers are aimed to reduce environmental sources of natural background radiation that would interfere with the measurements of radionuclides emitting low energy photons. The shielding reduces background in two orders of magnitude in the energy range of the photons of $662 \mathrm{keV}$ emitted by ${ }^{137} \mathrm{Cs}$ [4].

\subsection{Detection system}

The detection system installed in the IRD whole-body counter includes semiconductor and scintillation detectors with specific applications.

An array of four high-resolution high purity germanium detectors (HPGe) is used to perform lowenergy measurements of radionuclides emitting photons in the energy range from 10 to $200 \mathrm{keV}$ in the lungs, liver and bone tissue.

High energy measurement of photon-emitting radionuclides in the range from 100 to $3000 \mathrm{keV}$ in the whole body and in specific organs such as lungs, liver and thyroid are performed with two $\mathrm{NaI}(\mathrm{Tl})$ scintillation detectors, with dimensions of 8 "x4" and 3"x3".

The detectors supports allow positioning over various parts of the body of an individual laid on a comfortable monitoring chair.

\subsection{Calibration procedures}

The detection systems are calibrated with physical anthropomorphic phantoms of the organ of interest containing certified activities of the radionuclide of interest.

The calibration process consists of measuring the phantoms at standard geometries. Similarly, an inert phantom is measured to estimate the background count rate (Oliveira, 1999). It is important to point out that the quality of the measurement and consequently the reliability of the results relies, among other factors, on the calibration procedure adopted. The calibration factor, expressed in $\mathrm{cpm} / \mathrm{Bq}$, for each specific geometry and radionuclide is calculated as the ratio between the net count rate and the activity of the phantom.

\subsection{Calculation of activity in the body}

The activity of an exposed individual is calculated by dividing the net count rate registered on the in vivo measurement by the calibration factor. In the case of a lung measurement of a radionuclide 
emitting photons of low energy it is also necessary to correct the count rate due to the attenuation related to the chest thickness (CWT) of the tissue over the lung region [5]. Such correction is carried out considering individual's weight ( $\mathrm{kg})$ and height $(\mathrm{m})$.

The total uncertainty of the in vivo measurement is associated to the uncertainty of the calibration factor and the counting of the individual. The uncertainties associated to the various parameters of the calculation and the quality control of the detection systems are estimated according to well established international criteria [6].

\subsection{Evaluation of system sensitivity}

The minimum detectable activity (MDA) is calculated for each radionuclide and counting geometry. It is directly proportional to the square root of the background of an unexposed individual [7] as shown in Equation 1:

$$
M D A=\frac{4.65 \sqrt{N}}{E \times T}+\frac{3}{E \times T}
$$

Where MDA is the minimum detectable activity, in $\mathrm{Bq} ; \mathrm{N}$ is the total counts in the region of interest of the background of an unexposed individual; $\mathrm{E}$ is the calibration Factor, in (cpm/Bq), and $\mathrm{T}$ is the count time, in minutes.

The committed effective doses for the most relevant radionuclides is estimated using biokinetic and dosimetric models developed by the International Commission on Radiological Protection (ICRP) and suggested by the International Atomic Energy Agency (IAEA). ICRP classifies the compounds into three categories according to their solubility in the pulmonary fluids: Type F (very soluble), Type M (moderately soluble), and Type S (insoluble).

In this work, activities and doses are estimated with the software AIDE [8], allowing the interpretation of in vivo measurements and the comparison of the internal doses with the limits established by the Regulatory Board. The use of the software AIDE allows the calculation of the activities of radionuclides in the organs and tissues of interest 24 hours after the intake of respective activities that would result in committed effective doses of 1 and $20 \mathrm{mSv}$.

Table 1 presents a list of measurements performed at the IRD whole body counter and the parameters used for the calculation of doses for selected radionuclides, considering single intake via inhalation of inhalable particles with Activity Median Aerodynamic Diameter (AMAD) equal to 
$1 \mu \mathrm{m}$. In the specific cases of ${ }^{131} \mathrm{I}$ and ${ }^{123} \mathrm{I}$ it was assumed the intake of volatile elemental iodine, class F.

Table 1. List of measurements performed at the IRD whole body counter and corresponding activities of selected radionuclides in organs of interest, 1 day after the intake of $1 \mathrm{~Bq}$ via inhalation $\left(\mathrm{m}_{\mathrm{t}}\right)$

\begin{tabular}{|c|c|c|c|c|c|}
\hline Nuclide & $\begin{array}{c}\text { Organ } \\
\text { of interest }\end{array}$ & Detector & $\begin{array}{c}\text { Scenario } \\
\text { 1Type/ } \\
{ }^{2} \text { AMAD }\end{array}$ & $\begin{array}{c}\text { Dose } \\
\text { Coefficient } \\
\left(\mathbf{m S v} \cdot \mathbf{B q}^{-1}\right)\end{array}$ & $\begin{array}{c}\mathbf{m}(\mathbf{t}) \\
(\mathbf{B q} / \mathbf{B q})\end{array}$ \\
\hline${ }^{241} \mathrm{Am}$ & Lungs & HPGe & $\mathrm{M} / 1$ & $3.91 \times 10^{-5}$ & $1.09 \times 10^{-1}$ \\
\hline${ }^{241} \mathrm{Am}$ & Head & HPGe & $\mathrm{M} / 1$ & $3.91 \times 10^{-5}$ & $9.10 \times 10^{-4}$ \\
\hline${ }^{137} \mathrm{Cs}$ & Whole Body & $\mathrm{NaI}(\mathrm{Tl}) 8 " \mathrm{x} 4 "$ & $\mathrm{M} / 1$ & $1.20 \times 10^{-5}$ & $4.03 \times 10^{-1}$ \\
\hline${ }^{18} \mathrm{~F}$ & Whole Body & $\mathrm{NaI}(\mathrm{Tl}) 3 " x 3 "$ & F / 1 & $3.00 \times 10^{-8}$ & $4.58 \times 10^{-5}$ \\
\hline${ }^{18} \mathrm{~F}$ & Head & $\mathrm{NaI}(\mathrm{Tl}) 3$ "x3" & $\mathrm{F} / 1$ & $3.00 \times 10^{-8}$ & $3.70 \times 10^{-6}$ \\
\hline${ }^{131} \mathbf{I}$ & Thyroid & HPGe & $\mathrm{F}$, Gas & $1.98 \times 10^{-5}$ & $2.29 \times 10^{-1}$ \\
\hline${ }^{123} \mathrm{I}$ & Thyroid & HPGe & F, Gas & $2.13 \times 10^{-7}$ & $7.09 \times 10^{-2}$ \\
\hline${ }^{210} \mathrm{~Pb}$ & Head & HPGe & $\mathrm{M} / 1$ & $9.23 \times 10^{-4}$ & $5.07 \times 10^{-4}$ \\
\hline${ }^{210} \mathrm{~Pb}$ & Knee & HPGe & $\mathrm{M} / 1$ & $9.23 \times 10^{-4}$ & $3.87 \times 10^{-4}$ \\
\hline${ }^{210} \mathrm{~Pb}$ & Lungs & HPGe & $\mathrm{M} / 1$ & $9.23 \times 10^{-4}$ & $1.09 \times 10^{-1}$ \\
\hline${ }^{226} \mathrm{Ra}$ & Lungs & $\mathrm{NaI}(\mathrm{Tl}) 8 " \mathrm{x} 4 "$ & $\mathrm{M} / 1$ & $3.14 \times 10^{-3}$ & $1.09 \times 10^{-1}$ \\
\hline${ }^{232} \mathrm{Th}$ & Lungs & HPGe & $\mathrm{M} / 1$ & $4.24 \times 10^{-2}$ & $1.09 \times 10^{-1}$ \\
\hline${ }^{235} \mathrm{U}$ & Lungs & $\mathrm{NaI}(\mathrm{Tl}) 8 " \mathrm{x} 4 "$ & $\mathrm{M} / 1$ & $2.75 \times 10^{-3}$ & $1.09 \times 10^{-1}$ \\
\hline
\end{tabular}

${ }^{1}$ Solubility class according to ICRP 78; ${ }^{2}$ Activity Median Aerodynamic Diameter $(\mu \mathrm{m})$

\section{RESULTS AND DISCUSSION}

Table 2 presents the calibration results of the HPGe and $\mathrm{NaI}(\mathrm{Tl})$ detection systems available at the IRD whole body counter, for a variety of radionuclides, and an evaluation of the sensitivity of the detection system based on a comparison of the minimum detectable activities with the corresponding expected activities in the organs or tissues of interest associated to the respective committed effective doses of 1 and $20 \mathrm{mSv}$.

Uncertainties associated to the calibration factors and the efficiency values based on efficiency vs energy curves are estimated through the propagation of counting statistics and standard source activity uncertainty, and are below $2 \%$ in all cases.

The calibration factors obtained for the various counting geometries present uncertainties in the range of 0.5 to $7 \%$, which is compatible with values usually found in the literature related to in vivo measurement procedures [9]. 
It should be highlighted that MDA values for the radionuclides and geometries evaluated in this work refer to the application of the in vivo monitoring technique in situations where it is assumed a single incidental intake.

Table 2. Calibration Factors for the radionuclides monitored in the IRD whole body counter and comparison between MDA of the IRD whole body counter detection system and expected activities in measured organ 24 hours after an intake corresponding to committed effective doses of 1 and $20 \mathrm{mSv}$

\begin{tabular}{|c|c|c|c|c|c|}
\hline \multirow[t]{2}{*}{ Nuclide } & \multirow{2}{*}{$\begin{array}{l}\text { Geometry } \\
\text { (organ) }\end{array}$} & \multirow{2}{*}{$\begin{array}{l}\text { Calibration Factor } \\
\quad(\mathbf{c p m} / \mathbf{B q})\end{array}$} & \multicolumn{2}{|c|}{$\begin{array}{c}\text { Activity in measured organ } \\
(\mathrm{Bq})\end{array}$} & \multirow{2}{*}{$\begin{array}{r}\text { MDA } \\
(\mathbf{B q})\end{array}$} \\
\hline & & & $1 \mathrm{mSv}$ & $20 \mathrm{mSv}$ & \\
\hline${ }^{241} \mathrm{Am}$ & Lungs & $0.5229 . \mathrm{e}^{(-0.039 . \mathrm{CWT})}$ & 2.8 & 56 & 6.8 \\
\hline${ }^{241} \mathrm{Am}$ & Head (skull) & $0.389 \pm 0.003$ & $2.3 \times 10^{-2}$ & $4.6 \times 10^{-1}$ & 2.1 \\
\hline${ }^{18} \mathrm{~F}$ & $\begin{array}{l}\text { Whole Body } \\
\text { (skeleton) }\end{array}$ & $0.40 \pm 0.02$ & 1500 & 30000 & 32 \\
\hline${ }^{18} \mathrm{~F}$ & Head (brain) & $0.737 \pm 0.004$ & 180 & 36000 & 7.5 \\
\hline${ }^{131} \mathrm{I}$ & Thyroid & $0.397 \pm 0.005$ & $1.2 \times 10^{4}$ & $2.4 \times 10^{5}$ & 23 \\
\hline${ }^{123} \mathrm{I}$ & Thyroid & $0.394 \pm 0,022$ & $3.3 \times 10^{6}$ & $6.6 \times 10^{7}$ & 5.0 \\
\hline${ }^{210} \mathrm{~Pb}$ & Head (skull) & $0.039 \pm 0.003$ & 0.55 & 1.1 & 16 \\
\hline${ }^{210} \mathrm{~Pb}$ & Knee & $0.046 \pm 0.01$ & 0.42 & 8.4 & 14 \\
\hline${ }^{210} \mathrm{~Pb}$ & Lungs & $0.0501 \mathrm{e}^{(-0.04 . C W T)}$ & 120 & 2400 & 34 \\
\hline $\mathrm{F} \& A$ & Whole Body & $0.00422 \mathrm{e}^{(-0.000759 . \mathrm{E})}$ & $3.4 \times 10^{6}$ & $6.8 \times 10^{7}$ & 88 \\
\hline${ }^{226} \mathrm{Ra}$ & Lungs & $0.0345 . \mathrm{e}^{(-0.034 . \mathrm{CWT})}$ & 60 & 120 & 83 \\
\hline${ }^{232} \mathrm{Th}$ & Lungs & $2.27 \pm 0.01$ & 2.6 & 52 & 6.1 \\
\hline${ }^{235} \mathrm{U}$ & Lungs & $0.4544 \mathrm{e}^{(-0.0344 . C W T)}$ & 40 & 800 & 6.5 \\
\hline
\end{tabular}

$\mathrm{F} \& \mathrm{~A}=$ Fission and Activation Products; CWT $=$ Chest wall thickness $(\mathrm{mm}) ; \mathrm{E}=$ Energy $(\mathrm{keV})$

A comparative analysis between the results for head and knee geometries, for the radionuclides ${ }^{241} \mathrm{Am}$ and ${ }^{210} \mathrm{~Pb}$, shows that the methodologies are not sensitive enough if the measurement is performed up to 24 hours after the intake. This limitation is related to the biokinetic behavior of those nuclides in human body and their respective dose coefficients. It happens in these cases that the corresponding retention fractions in bone tissue is quite low one day after the intake, resulting in an activity level in the compartment below the minimum detectable activity of the technique.

In the case ${ }^{226} \mathrm{Ra}$ and ${ }^{232} \mathrm{Th}$, the techniques are suitable only for the detection of activity levels that would result in doses slightly below $20 \mathrm{mSv}$, considering the intake of those radionuclides without their respective progeny. 
On the other hand, in the case of ${ }^{18} \mathrm{~F}$, considering its low dose coefficient, the techniques can be considered suitable for the detection of low doses even 24 hours after the intake, since the activity in the compartments corresponding to an effective dose of $1 \mathrm{mSv}$ is approximately two orders of magnitude higher than the minimum detectable activity.

In other cases, like the measurement of ${ }^{131} \mathrm{I}$ and ${ }^{123} \mathrm{I}$ in the thyroid, ${ }^{210} \mathrm{~Pb}$ and ${ }^{235} \mathrm{U}$ in the lungs, and ${ }^{137} \mathrm{Cs}$ in the whole body, the techniques are comfortably sensitive for their application in the evaluation of accidental intakes.

\section{CONCLUSION}

The IRD whole body counter is able to perform in vivo measurement of a large variety of radionuclides emitting photons in the energy range from 10 to $3000 \mathrm{keV}$.

The minimum detectable activities for most of the radionuclides of interest allow its application in the case of accidental intakes.

The use of in vivo techniques for routine monitoring of occupationally exposed workers must take into account that the minimum detectable activity should be below the expected activity in the compartment of interest, considering the most likely exposure scenario as well as the monitoring frequency established in the Radiation Protection Plan implemented in the facility.

\section{ACKNOWLEDGMENT}

The authors would like to acknowledge and highlight the invaluable efforts and dedication of Dr Carlos Alberto Nogueira de Oliveira, responsible for building and setting up the IRD whole body counter, back in the 80's. We would also like to thank Dr Maria Cristina Lourenço, who have been in charge of the facility in the 90's and Dr Gerard Laurer (in memorian) who provided basic and advanced training to the whole body counter staff in early years. 


\section{REFERENCES}

[1] CNEN - Comissão Nacional de Energia Nuclear. Diretrizes Básicas de Proteção Radiológica. Norma CNEN-NN-3.01, 2005

[2] ICRP - International Commission on Radiological Protection. Individual Monitoring for Internal Exposure of Workers. Publication 78, 1998

[3] IAEA - International Atomic Energy Agency. Assessment of Occupational Exposure Due to Intakes of Radionuclides" Safety Standards Series RS-G-1.2, 1999

[4] OLIVEIRA, C.A.N.; LOURENÇO, M.C.; DANTAS, B.M.; LUCENA, E.A. and LAURER, G.R. The IRD/CNEN whole body counter: Background and calibration results. Radiat. Prot. Dosm, v.29 (3), p. 203-208, 1989

[5] KRUSHTEN, D.A. and ANDERSON, L. Improved ultrasonic measurement techniques applied to assay of Pu and other transuranics in lung. Health Physics, v. 59 (1), p. 117, 1990.

[6] ISO - International Standards Organization - General requirements for the competence of testing and calibration laboratories. ISO 17025, 2005

[7] ISO - International Standards Organization - Radiation protection - Performance criteria for radiobioassay, Part 1: General Principles. ISO 12790-1, 2001

[8] BERTELLI, L.; MELO, D.R.; LIPSZTEIN, J. and CRUZ-SUAREZ, R. "AIDE: Internal Dosimetry Software” Radiat. Prot. Dosm. v.130 (3) p.358-367, 2008

[9] International Atomic Energy Agency. Methods for Assessing Occupational Radiation Doses 